Jameson A, Paris C, Tasso C, edsProceedings of the sixth international con 23 McGarry E, Jones R, Cowan B, White J. A multimedia system for person ference on user modellingew York: Springer Wien, 1997:107,18.

10 Kreuter MW, Strecher VJ. Do tailored behavior change messages enhance the effectiveness of health risk appraisal? Results from a randomized trial. Health Educ Res 996;11:97,105.

11 Department of Health. NHS information for healthLondon: DoH, 1998

12 Hathaway D. Effect of preoperative instruction on postoperative outcomes: a meta-analysis.Nurs Res1 986;35:269,75

13 Schwartz LP, Brenner ZR. Critical care unit transfer: reducing patient stress through nursing interventions. Heart Lung 1979;8:540,7

14 Gilhooly MLM, McGhee SM. Medical records: practicalities and principles of patient possession. J Med Ethics 1991:17:138,43.

15 Hinds C, Streater A, Mood D. Functions and preferred methods of receiving information related to radiotherapy. Cancer Nurs 1995;18: 374,83

16 Jones RB, Pearson J, McGregor S, Cawsey A, Barrett A, Gilmour H, et al. Cross sectional survey of patients' satisfaction with information about cancer.BMJ 1999;319:1247,8.

17 Zigmond AS, Snaith RP. The hospital anxiety and depression scale. Acta Psychiatr Scand983;67:361,70.

18 Watson M, Greer S, Young J, Inayat Q, Burgess C, Robertson B. Develop, ment of a questionnaire measure of adjustment to cancer: the MAC scale. Psychol Med 988;18:203,9.

19 Jones RB, Knill,Jones RP.Electronic patient record project: direct patient input to the record. Report for the Strategy Division of the Information Managemerßo Group of the NHS ME Glasgow: University of Glasgow, 1994.

20 Glimelius B, Birgegrd G, Hoffman K, Kvale G, Sjoden P. Information to and communication with cancer patients: improvements and psychologis cal correlates in a comprehensive care program for patients and their relatives. Patient Educ Couns $1995 \cdot 25: 171,82$

21 Luker KA, Beaver K, Leinster SJ, Owens RG. Information needs and sources of information for women with breast cancer: a follow sup study. J Adv Nurs 1996;23:487,95

22 Jones RB, Navin LM, Murray KJ. Use of a community'based touch,screen public access health information system. Health Bull 1993;51:34,42.

McGarry E, Jones R, Cowan B, White J. A multimedia system for person, alised treatment of anxiety in primary care. In: Richards B, ed. Curren perspectives in healthcare computikgybridge: BJHC Books, 1998: 277,85.

24 Morton AR, Patterson L, Jones R, Atkinson JM, Coia D. Personalised patient information for patients with schizophrenia living in the commu nity. In: Richards B, ed. Current perspectives in healthcare computing Weybridge: BJHC Books, 1998: 94,104

25 Bailey AJ, Parmar MKB, Stephens RJ for the CHART Steering Committee. Patient,reported shortsterm and longterm physical and psychologic symptoms: results of the continuous hyperfractionated accelerated radiotherapy (CHART) randomised trial in non,smallscell lung cancer. J Clin Oncol1998;16:3082,93.

26 Rapoport Y, Kreitler S, Chaitchik S, Algor R, Weissler K. Psychosocial problems in head,and,neck cancer patients and their change with time since diagnosis.Ann Oncol1993:4:69;73.

27 Hall A, A'Hern R, Fallowfield L. Are we using appropriate self,report questionnaires for detecting anxiety and depression in women with early breast cancer?Eur J Cancer1 999:35:79,85.

28 Dunn SM, Butow PN, Tattersall MHN, Jones QI, Sheldon JS, Taylor JJ, et al. General information tapes inhibit recall of the cancer consultation. J Clin Oncol 1993;11:2279,85.

29 Tattersall MHN, Butow PN, Griffin AM, Dunn SM. The take home message: patients prefer consultation audiotapes to summary letters. $J$ Clin Oncol 1994;12:1305,11.

Miller SM. Monitoring versus blunting styles of coping with cancer influ ence the information patients want and need about their disease: impli cations for cancer screening and management. Cancer1995;76:167,77.

31 Street RL Jr, Voigt B, Geyer C Jr, Manning T, Swanson GP. Increasing patient involvement in choosing treatment for early breast cancer. Cancer 1995:76:2275,85

32 McHugh P, Lewis S, Ford S, Newlands E, Rustin G, Coombes C, et al. The efficacy of audiotapes in promoting psychological well,being in cancer patients: a randomised, controlled trial. Br J Cancer1 995;71:388,92.

(Accepted 11 October 1999)

\title{
Cross sectional survey of patients' satisfaction with information about cancer
}

\author{
Ray Jones, Janne Pearson, Sandra McGregor, W Harper Gilmour, Jacqueline M Atkinson, \\ Ann Barrett, Alison J Cawsey, Jim McEwen
}

Most patients with cancer want as much information as possible appropriate to their personal needs and

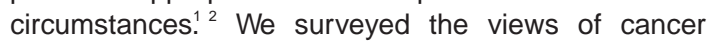
patients entering a randomised trial of computer based information. ${ }^{3}$ We examined their need for information and their satisfaction with information received and how these varied with their demographic, social, and psychological characteristics.

\section{Patients, methods, and results}

Eligible patients were those planned to receive radical radiotherapy, who knew their diagnosis, were without visual or mental handicap, and were without severe pain or symptoms causing distress. Of 715 patients asked to take part, 190 refused, 25 stating they did not want more information. Of the 525 participants, 309 had breast cancer, 129 had prostate cancer, 22 had cer, vical cancer, and 65 had laryngeal cancer.

Data were collected at the recruitment interview, from a questionnaire the patients completed at home shortly after, and from their case notes. Data included the information patients would like, ${ }^{2}$ a hospital anxiety and depression scale, the newspaper patients read, and deprivation category (derived from postcode). ${ }^{5}$ Using ${ }^{2}$ tests and multiple logistic regression analysis, we compared the patients' sources and perceived quantity of information received and their satisfaction with this information, as binary variables, with their age, sex, cancer site, newspaper read (tabloid $v$ broadsheet), deprivation category, and anxiety and depression scores (table). Information need ("as much as possible" $v$ other) was considered both as a response variable and as a predictor of sources and satisfaction.

Four out of five patients wanted as much information as possible. In univariate analysis, newspaper read, deprivation category, having a connection with the health service, age, and time since diagnosis were predictors of information need. In mul, tiple logistic regression analysis, however, only newspaper read and age remained predictors.

One in five patients were not satisfied with the information given. Univariate analysis showed that dis satisfied patients were much more likely to be depressed and were marginally more likely to be anxious or to want as much information as possible. In multiple logistic regression age, sex, and depression were predictors of dissatisfaction. Fifteen per cent of patients said there had been many differences in what they had been told by health professionals. Multiple logistic regression showed that these patients were more likely to be anxious.

Patients with breast cancer and readers of broadsheets had received more information and from more people than patients with other cancers but were not significantly more likely to be satisfied. The location of the clinician who gave the diagnosis had no effect on how much information patients had received. Younger depressed patients who wanted as much information as possible were less likely to be satisfied even though they had received more information than others. A third of patients said there were other things that they
Department of Public Health, University of Glasgow, Glasgow G12 8RZ

Ray Jones senior lecturer in health informatics Janne Pearson research assistant

Sandra McGregor research assistant W Harper Gilmour senior lecturer in medical statistics Jacqueline $M$

Atkinson senior lecturer in behavioural sciences Jim McEwen professor of public health

Beatson Oncology Centre, Western Infirmary, Glasgow G11 6NT

Ann Barrett professor of radiation oncology

continued over 
Percentage (number) of cancer patients agreeing with various statements about the information they had received before starting radiotherapy

\begin{tabular}{|c|c|c|c|c|c|}
\hline & $\begin{array}{l}\text { Given } \\
\text { information } \\
\text { from few } \\
\text { people } \\
\text { (v many) }\end{array}$ & $\begin{array}{l}\text { Not given } \\
\text { much } \\
\text { information }\end{array}$ & $\begin{array}{l}\text { Many } \\
\text { differences } \\
\text { in } \\
\text { information } \\
\text { given }(v \text { few } \\
\text { or none })\end{array}$ & $\begin{array}{l}\text { Would like to } \\
\text { have been } \\
\text { given other } \\
\text { information }\end{array}$ & $\begin{array}{c}\text { Non>committal } \\
\text { or } \\
\text { dissatisfied } \\
\text { with } \\
\text { information } \\
\text { given } \\
\text { (v satisfied) }\end{array}$ \\
\hline \multicolumn{6}{|l|}{ Age: } \\
\hline$<60$ & $73(193)$ & 49 (112) & $18(45)$ & $36(93)$ & $21(56)$ \\
\hline$>60$ & $82(207)^{\star}$ & $59(119)$ & $13(31)$ & $32(77)$ & $17(43)$ \\
\hline \multicolumn{6}{|l|}{ Sex: } \\
\hline Female & $71(240)$ & $46(131)$ & $17(55)$ & $33(109)$ & $17(58)$ \\
\hline Male & $89(160)^{*}$ & $69(100)^{*}$ & $12(21)$ & $35(61)$ & $23(41) \dagger$ \\
\hline \multicolumn{6}{|l|}{ Cancer site: } \\
\hline Breast & $70(213)$ & $44(116)$ & $16(48)$ & $33(99)$ & $17(52)$ \\
\hline Other & $89(187)^{*} \dagger$ & $69(115)^{*} \dagger$ & $14(28)$ & $35(71)$ & $23(47)$ \\
\hline \multicolumn{6}{|c|}{ Time since diagnosis (months): } \\
\hline$<3$ & $79(205)$ & $57(118)$ & $13(32)$ & $29(73)$ & $19(48)$ \\
\hline $4-12$ & $73(162)$ & $48(94)$ & $14(29)$ & $38(82)$ & $19(41)$ \\
\hline$>12$ & $97(28)^{\star}$ & $64(16)$ & $10(3)$ & $43(12)$ & $30(9)$ \\
\hline \multicolumn{6}{|l|}{ Where diagnosed: } \\
\hline Teaching hospital & $81(137)$ & $51(75)$ & $13(21)$ & $35(57)$ & $18(30$ \\
\hline Other hospital & 77 (215) & 56 (133) & $16(43)$ & $35(95)$ & $21(56)$ \\
\hline Elsewhere & $70(45)$ & $47(22)$ & $20(12)$ & $25(15)$ & $18(12)$ \\
\hline \multicolumn{6}{|c|}{ Deprivation category (Carstairs category): } \\
\hline Affluent (1+2) & $79(84)$ & $42(38)$ & $21(22)$ & 37 (39) & $19(20)$ \\
\hline Middle $(3+4)$ & 76 (159) & $52(94)$ & $14(28)$ & $33(67)$ & $17(35)$ \\
\hline Deprived $(5,7)$ & $79(153)$ & $62(95)^{*} \dagger$ & $14(26)$ & $34(64)$ & $23(44)$ \\
\hline \multicolumn{6}{|l|}{ Newspaper read: } \\
\hline Broadsheet & $73(143)$ & $44(71)$ & $16(31)$ & $34(66)$ & $16(32)$ \\
\hline Tabloid & $81(211) \dagger$ & $62(137)^{*} \dagger$ & $14(35)$ & $33(85)$ & $21(54)$ \\
\hline \multicolumn{6}{|l|}{ Connection with NHS: } \\
\hline Yes & $73(149)$ & $46(77)$ & $16(31)$ & $35(68)$ & $18(36)$ \\
\hline No & 80 (221) & $59(137)^{*}$ & $15(39)$ & $33(90)$ & $21(56)$ \\
\hline
\end{tabular}

Hospital anxiety and depression scale:

\begin{tabular}{l} 
Hospital anxiety and depression scale: \\
\begin{tabular}{lccccc}
\hline Anxiety: \\
\hline No & $81(261)$ & $53(141)$ & $12(38)$ & $28(83)$ & $16(49)$ \\
\hline Borderline & $73(75)$ & $52(44)$ & $14(14)$ & $35(34)$ & $23(23)$ \\
\hline Yes & $71(62)$ & $58(44)$ & $29(24)^{\star} \dagger$ & $54(46)^{*} \dagger$ & $27(23)$ \\
\hline Depression: & & & & & \\
\hline No & $77(346)$ & $51(190)$ & $13(58)$ & $31(134)$ & $17(74)$ \\
\hline Borderline & $80(37)$ & $64(27)$ & $37(15)^{\star}$ & $44(20)$ & $37(16)$ \\
\hline Yes & $88(15)$ & $86(12)^{*}$ & $19(3)$ & $71(12)^{*}$ & $50(8)^{*} \dagger$ \\
\hline Attitude to information: & & & & & \\
\hline As much as possible & $76(324)$ & $51(180)$ & $16(66)$ & $36(148)^{*} \dagger$ & $21(88)$ \\
\hline Only good news or & $84(67)$ & $67(43)^{*}$ & $12(9)$ & $20(15)$ & $12(9)$
\end{tabular} \\
\hline
\end{tabular}

no details

\begin{tabular}{llllll}
\hline All patients & $78(400 / 516)$ & $54(231 / 430)$ & $15(76 / 494)$ & $34(170 / 503)$ & $19(99 / 509)$
\end{tabular}

${ }^{*}$ Significant predictors $(P<0.01)$ in analysis. $\dagger$ Significant predictors $(P<0.05)$ in multiple logistic

regression analysis.

Department of Computer Science,

Heriot Watt

University,

Edinburgh

EH14 4AS

Alison J Cawsey

lecturer in computer

science

Correspondence to:

R Jones

r.b.jones@udcf.gla. ac.uk would like to have been told. Patients most commonly required further information on the effects of treatment and prognosis and recovery.

\section{Comment}

One in five of 525 patients starting radiotherapy were not satisfied with the information they had received. Breast cancer patients were better provided with information than patients with other cancers but were not necessarily more satisfied with it as a result. More should be done to help patients with other cancers obtain suitable information.

Three of the outcome measures were associated with anxiety or depression. The nature of the relation of anxiety, depression, and information among cancer patients would be worthy of further study.
As in other work, ${ }^{2}$ we found that most cancer patients wanted as much information as possible. However, our percentage slightly overestimates this, as refusal to take part in the study might indicate lack of desire for further information. Although those patients living in affluent areas wanted more information, type of newspaper read was a better indicator of information need. Few studies have used this intuitively obvious indicator, and we suggest its use, among older patients, in both clinical practice and research.

We thank the consultants (particularly Nick Reed and Tim Habeshaw, who were directors of the Beatson Oncology Centre during the study), other medical staff, cancer nurse specialists, radiographers, medical records staff, and other staff at the Beatson Oncology Centre for their collaboration with this project; the patients who took part in the study; Lynn Naven, who worked as a locum for SMcG during three months' sick leave; Ed Carter; Ross Morton and Keith Murray, who helped with various aspects of computing; Charles Gillis and Cathy Meredith, who advised on research design; Sally Tweddle, who made available unpublished protocols and papers; and colleagues in the University of Glasgow and the Beatson Oncol' ogy Centre who commented on the manuscript.

Contributors: RJ had the original idea for the study, designed the study, was the main grant holder, supervised the research assistants, analysed the data, and wrote the paper. JP carried out the pilot study, contributed to the design, was a research assistant with day to day responsibility for data collec tion and running the study, undertook preliminary analysis, and contributed to final analysis and editing of paper. SMcG contributed to the design of the study, was a research assistant with day to day responsibility for data collection and running the study, undertook some preliminary analysis, and edited the paper. WHG advised on design of the study and analysis of the data and edited the paper. JMA advised on the design of the study and choice of psychological measures, edited the paper, and was a grant holder. AB discussed the original idea, set up opportunities for the pilot study and main study, contributed to the design of the study, edited the paper, and was a grant holder. AJC discussed the original idea, contributed to the design of the study, discussed the analysis of data, edited the paper, and was a grant holder. JMcE discussed the original idea, set up opportu nities for the pilot study and main study, edited the paper, and was a grant holder. RJ and $A B$ are guarantors for the study.

Funding: Scottish Office Home and Health Department grant number K/OPR/2/2/D248. The views expressed in this paper are those of the authors and do not represent the views of the Scottish Office.

Competing interests: None declared.

1 National Cancer Alliance. Patient>centred cancer services? What patients say Oxford: National Cancer Alliance, 1996.

Meredith C, Symonds P, Webster L, Lamont D, Pyper E, Gillis CR, et al. Information needs of cancer patients in west Scotland: cross sectional survey of patients' views.BMJ 1996;313:724:6

3 Jones R, Pearson J, McGregor S, Cawsey AJ, Barrett A, Craig N, et al. Ran domised trial of personalised computer based information for cancer patients. BMJ 1999;319:1241,7.

4 Zigmond AS, Snaith RP. The hospital anxiety and depression scale. Acta Psychiatr Scand 983;67:361,70.

5 Carstairs V, Morris R. Deprivation and health in ScotlanđAberdeen: Aber deen University Press, 1991

(Accepted 11 October 1999)

\section{Endpiece \\ Bill Gates's strength}

The fox knows many things; the hedgehog knows one big thing; the 800 pound gorilla doesn't give a shit what anybody knows. [Bill] Gates's great strength was in combining all these attributes.

\section{John Lanchester, London Review of Books} September 1999, p 5. 